\title{
INFLUENCE OF TANGIBLE ECOSYSTEM GOODS ENCROACHMENT ON HOST COMMUNITY WELL-BEING: A CASE OF BWINDI IMPENETRABLE NATIONAL PARK
}

\author{
Wanyera Francis ${ }^{1}$, Dr. Mutugi Chira Robert ${ }^{2}$, \\ Dr. Najma Dharani ${ }^{3}$ and Prof. Gichuki Nathaniel ${ }^{4}$ \\ ${ }^{1}$ University of Tourism, Technology and Business studies: Department of Tourism. \\ ${ }^{2}$ University of Nairobi; Department of Biological Sciences. \\ ${ }^{3}$ School of Pure and Applied Sciences, Kenyatta University. \\ ${ }^{4}$ University of Nairobi: Department of Biological Sciences.
}

\begin{abstract}
Cite this article:
Wanyera F., Mutugi C.R., Najma D., Gichuki N. (2021), Influence of Tangible Ecosystem Goods Encroachment on Host Community Well-being: A Case of Bwindi Impenetrable National Park. African Journal of Environment and Natural Science Research 4(4), 88-98. DOI: $10.52589 / A J E N S R-$ UXMAKZDP.
\end{abstract}

\section{Manuscript History}

Received: 22 June 2021

Accepted: 14 July 2021

Published: 19 Oct 2021

Copyright $(9) 2020$ The Author(s). This is an Open Access article distributed under the terms of Creative Commons AttributionNonCommercial-NoDerivatives 4.0 International (CC BY-NC-ND 4.0), which permits anyone to share, use, reproduce and redistribute in any medium, provided the original author and source are credited.
ABSTRACT: The study was set out to investigate how encroachment on ecosystem tangible goods improves the host community well-being. The problem was that over harvesting of the tangible goods resulted in the degradation of the ecosystem and thus affected the quality and quantity of the tangible goods harvested and thus negatively affected the host community's wellbeing. The study had threefold objectives and these were; to describe the ecosystem destruction trends; to determine the driving forces behind the encroachment of the park ecosystems and, to ascertain the different ecosystem tangible goods harvested from the park. The literature of the study focused on local community wellbeing and encroachment as well as the causes of rampant encroachment of the ecosystems both in unprotected areas and in protected areas. The methodology of this study was majorly descriptive and considered the population of 40 households and a sample of 32 households as well the household used as a sampling unit. The results indicated that encroachment on ecosystems occurred and as a result the ecosystem size dwindled over the past three decades. Also, the results revealed that the major cause of this encroachment was scarcity of land and poverty. Whereas the most demanded ecosystem resources were timber and fuel wood. It was concluded that because there was no wellbeing amongst the host community due to poverty and scarcity of land, they were forced to encroach on the ecosystem resources. It was therefore recommended that the park and host community should find mechanisms to empower the host community in order to minimize encroachment rates.

KEYWORDS: Encroachment, Wellbeing, Ecosystems, Tangible, Goods, Community 


\section{INTRODUCTION AND BACKGROUND}

Globally, the concept of ecosystem goods, services and natural capital have in the recent past been developed to make clear the linkage between human wellbeing, ecosystems and ecological sustainability for policy, development and conservation (MEA, 2005; Sachs and Reid 2006). Recent efforts have indicated that incorporating ecosystem services into land-use decisions characteristically favours local community wellbeing, conservation activities as well as sustainability of conversion of intact ecosystems (Balmford et al 2002; Turner et al 2003)

Ecosystem services and goods are presumed to be benefits that humans enjoy from ecosystems and as such the Millennium Ecosystem Assessment (MEA), categorized them into four sections namely; provisioning, regulating, supporting and cultural services (Allen et., al 2011). Ecosystems offer tangible renewable goods such as food, fuel wood, fiber, water and medicinal plants among others. While the tangible services include the processes that generate the tangible goods (Greenfacts 2015). While protected areas are looked at as management tools that are designed to conserve the natural capital. In the same line, ecosystem conservation aims at understanding the interactions of man and ecosystems and how to manage them to have an enabling environment for sustainability (Groom., et al 2006).

At the global scale man depends on the ecosystem in a variety of ways. As a result of this dependency there is continuous modification of ecosystems to harvest the ecological renewable goods and services. This is linked to human population growth which creates demand for their consumption (Williams 2011). Researchers have highlighted four common elements of human ecosystem modification and include simplification of the ecosystems, reduction in natural variability, fragmentation of ecosystems processes and introduction of hard boundaries (Turner., 2001).

Early studies indicate that unsustainable activities have led to depletion of certain renewable ecosystem goods which has resulted in alteration and collapse of particular ecosystems, change in its functions and loss of some or all of goods or services associated with adjoining ecosystems. Also, extensive deforestation around the Malaysian capital Kuala Lumpur led to loss of water reservoirs and triggered water rationing in 1998 and decline continued until for the first time it imported water (Butler 2009).

Nevertheless Butler (2009) argued that demand for ecosystem renewable goods and services has grown, and directly impacts negatively on the poor community that have lost access to dwindled renewable goods. For instance, large amounts of fish on the western African coast has been harvested by the western countries which has made the local people run short of fish which was their food and source of income (Greenfacts, 2005). In the same vein, (Lester, 2009) emphasized that forest ecosystems act as homes to approximately 300 million lives globally, $30 \%$ of whom are the indigenous while 800 million rely on forest ecosystems for their wellbeing. Additionally, $75 \%$ of the 2.6 billion individuals who survive on less that two dollars a day are known to be dependent upon the local natural resources for their livelihood (UNEP, and World Bank 2008).

In a similar way (Geist and Lambin, 2002) found out the poor are usually the ones who are highly dependent on the ecosystem renewable goods and services because these ecosystems generate several resources namely food, medicine, fuelwood, timber products, revenue from small businesses and construction materials. For example about a billion human beings use and 
live in bamboo houses where bamboo offers protection on the outside of their built houses ( Bell and Morrison, 2015). On the contrary anthropogenic activities if poorly handled can result in negative results that accelerate depletion and destruction of renewable ecosystem goods and services as well as higher production costs.

Apart from that, the ecosystems are not islands and so they are closely linked and always interacting with a wide range of species that compose them, the ecosystem services involved, ecosystem functions and related phenomena. This therefore implies that perturbation of one section of the ecosystem, disrupts negatively proper functioning of the entire system (Falvio, 2008). De Groot and Boumans, (2002), also highlighted that as a result of ecosystem disturbance, may arise due to the impacts from sectoral activities which directly depend on the natural capital such as fishing, agriculture, mining and grazing and so need to be assessed before grave mistakes are made. In the same line the consequences of such as timber harvest, water harvest, and fertile soil use need to be assessed in light of the extent of their disturbance on ecosystem renewable goods and services by the local community.

Falvio, (2008) also added that in Rwanda, demand for ecosystem goods has grown over the past three decades in a way that tradeoffs among services and goods have become the order of the day. For example, a country can decide to increase food supply by converting a forest ecosystem to agriculture. Lester (2009) also added that this in turn affects the other intangible ecosystem goods derived from the forest ecosystems such as water purification, nitrogen cycle, carbon cycle, soil erosion control, and ecotourism and tangible renewable ecosystem goods such as timber products, food, fruits, fish and medicinal plants. Additionally, there are many indicators that show that ecosystem goods demand and services will grow over the next 30 decades (MA, 2005; Sachs and Reid, 2006).

Similarly, the challenge in Rwanda is brought about by the increasing demand for ecosystem renewable goods and services is complicated by the increasingly serious perturbation in terms of inability of the ecosystems to offer these benefits which affects the local community wellbeing (Geist, 2002). For instance, world fisheries stocks are dwindling, due to overfishing, while $40 \%$ of the suitable agricultural land has been degraded in the recent past by erosion, salinization, compaction, nutrient depletion, pollution, urbanization and settlements. Also, other anthropogenic induced problems include alteration of the nitrogen cycles, phosphorus, sulphur, and carbon cycle. These challenges in several parts of the world are greatly attributed to limited knowledge and understanding of the local community (Bogmann, et al 2000; Dasgupta, 2001). Other researchers (Williams, 2011; Greenfacts, 2005 and Geist, 2002) argued that ecosystem degradation tends to ham majorly the rural local community and has more direct and severe impact on economically poor people.

The depletion of the renewable ecosystem goods has great implications on the livelihood of the local community. This is because wellbeing has key aspects that must be noted, namely the basic material for a good life, freedom and choice, health, good social relations and security. Therefore, lack of ecosystem benefits disrupts the wellbeing of the local community in rural areas and poor countries (Pearce, 2006). Conversely human wellbeing can be improved through sustainable human interactions with ecosystems supported by necessary instruments, institutions, organizations and technology. The creation of these processes through participation of local community and transparency is likely to contribute to wellbeing in terms of freedoms and choice as well as improved economic, social and ecological security. Whereby 
ecological security means the ability to have sustainable ecological renewable goods and services that the local community can depend on (Rosegrant et al 2003; UNEP, 2008).

Interestingly Pearce (2006) mentioned that there are indicators which show that humans are using the ecosystems in a non-sustainable manner and yet ecosystems are assets that are similar to other capital assets that contribute to the flow of goods and services in a long run. This implies that if the ecosystems are depleted in a short run then human well being will be affected. In addition, the studies also reveal that in the past two decades ecosystems have been under increasing pressure from anthropogenic activities. In the same way, the MEA, 2005 highlighted that approximately $60 \%$ of the services provided by the ecosystems to man's wellbeing are observed to be declining.

As a result, the ecosystem renewal goods and services from the modification of the earth, have led to dwindling of the benefits. Similarly, there is general consensus that suggests that in the $21^{\text {st }}$ century man will face several pressing and complicated challenges that include conversion of ecosystems to large-scale decline in ecosystem renewable goods and services (MEA, 2005; Schrorer et al 2005). As a result, increasing poverty and water scarcity especially in developing countries is likely to dangerously drive climate systems (Schneider, 2001; Mastrandrea and Schneider 2004). Similarly, Myers and Worm 2004 agreed that these challenges were occurring on unprecedented scale and are most likely to be linked to growing societal demands especially in rural settings. Therefore, the mitigation measures require deeper analysis and articulation of the ecosystems and linkage to human existence as well as wellbeing (Schrorer et al 2005, Sachs and Reid, 2006).

\section{MATERIALS AND METHODS}

Bwindi Impenetrable National park is located in southwestern Uganda, along the border of Democratic Republic of Congo (Plumptre et al., 2004; ORTPN, 2005) The forest area represents one of the remnants of once extensive Afro-montane forests. It is known to support unique and endemic species that include mountain gorillas (Gorilla beringei beringei). The forest area is also surrounded by one of the highest population densities in the region. The park covers $331 \mathrm{~km}^{2}$ of jungle forest which consist of afro-montane and lowland forest cover. It was designated as a UNESCO-World Heritage Site (Plumptre et al., 2004). It has got several species of flora and fauna that are endemic to the forest and is located at $0^{0} 53^{\prime}-1^{0} 08$ ' $S, 29^{0} 35^{\prime} 29^{0} 50^{\prime}$ E. The park consists of steep sided hills and extends to an altitude range $1400 \mathrm{~m}$ rising to the highest point of $2607 \mathrm{~m}$ in the southwest and to the lowest $1190 \mathrm{~m}$ in the northeast. The topography is very rugged and $60 \%$ of the protected area has an elevation of $2000 \mathrm{~m}$. The area outside the park is majorly composed of fragmented land pieces that were cultivated by the adjacent local community. The population density is high and is estimated at 280 persons per $\mathrm{km}^{2}$ and majorly depends on subsistence farming (Lanjouw et al., 2001).

The study population was 40 households and the sampled households were 32 . The researcher used Slovin's formula to come up with the required sample. The sample of households were used and two elders in each household were used as the respondents for this study. The data collection procedure involved the following. All visible evidence of human activities like bean sticks harvest were noted and recorded. Boundary walks covered the purposely selected park areas heavily encroached by human activities. During the field study the researcher moved 
along the boundary. The survey involved moving along the park boundary in the selected study spots situated in the parishes selected as well as the park offices in Kinigi sector. The unit of measurement was the household with each contributing two respondents. Two adults in the household (mother and father) were selected for the interview. All these were randomly sampled and the park staff plus local authorities were purposively selected after placing them in strata. Anthropogenic activities were recorded from respondents, private woodlots and other drivers that influence ecosystem changes. Signs of anthropogenic activities were recorded at a distance of about 150 meters from the boundary. This was because earlier studies by (Olupot, 2009) indicated that most resources were harvested by local people within $300 \mathrm{~m}$ from the park boundary. The study used purposive and stratified sampling techniques especially among the local communities and the park staff. Purposive sampling method was used especially targeting those deemed to be knowledgeable and well versed with the aspects under study. Stratified sampling involved dividing the area of study in strata whereby the respondents were placed into three categories that included the top management, middle management and lower cadre staff, community leaders, community members and community mobilizers.

\section{RESULTS}

The purpose of the study was to investigate the effect of ecosystem encroachment on local community wellbeing. In that regard, taking 1973 as a base year, the results indicated that as the population increased, the ecosystem size kept dwindling. According to the Key informant, the ecosystem cover area by 1973 had an ecosystem cover area of 56.2\% in size. This was attributed to rapid population growth coupled with lack of agricultural land and thus deforestation. While the unprotected woodland ecosystem area was $29.4 \%$ of the total land surface, however, by 1987 the woodland ecosystem area had reduced to $9 \%$ and this was a result of increased demand for fuel wood and charcoal. Similarly, the protected ecosystem area had reduced to $54.8 \%$ due to deforestation for timber products. In the same vein the small scale farm ecosystems were $29.4 \%$ in 1973 but by 1987 the farm ecosystem area had increased to $30.2 \%$. This was similar to tea plantation ecosystems that covered $6.4 \%$ in 1973 but had reduced to $5.5 \%$ and all these phenomena were linked to the increasing population and demand for land for settlement. The Key informants added that by 2010 the protected area ecosystem area had reduced further by $2.9 \%$ to $51.9 \%$ this was due to increased population pressure and high demand for timber products for their wellbeing. Additionally, by 2015, the protected area ecosystem area had reduced further by $0.9 \%$ whereas in the same year the unprotected woodland ecosystem area had also reduced from $9 \%$ to $1,7 \%$ and further in 2020 by $-24 \%$. This decline in the size was attributed to clearance of woodlots for increased demand for agricultural areas as well as settlement areas. The results also revealed that the small scale farms progressively increased as observed in table 1 . For instance, it was found out that by 2010 , the small scale farms had increased to $33.5 \%$ from 30,2 in 2010 and further increased to $55.5 \%$ by 2020. This was highlighted by the respondents that increased demand for household sustenance through subsistence farming led to this trend. However, tea plantations, ecosystem areas and grazing land areas from 2010 to 2020 continued to dwindle. All these were attributed to acute shortage for land and thus rampant clearance of ecosystems by the local community for their wellbeing 


\begin{tabular}{|c|c|c|c|c|c|c|c|c|c|}
\hline & \multirow{2}{*}{$\begin{array}{l}1973 \\
\text { area } \\
\text { (ha } \\
x 100)\end{array}$} & \multirow{2}{*}{$\begin{array}{l}\text { Perce } \\
\text { ntage } \\
\text { cover } \\
1973\end{array}$} & \multirow{2}{*}{$\begin{array}{l}1987 \\
\text { area } \\
\text { (ha } \\
\text { x100) }\end{array}$} & \multirow{2}{*}{$\begin{array}{l}\text { Percent } \\
\text { age } \\
\text { cover } \\
1987\end{array}$} & \multirow{2}{*}{$\begin{array}{l}2010 \\
\text { area } \\
\text { (ha } \\
\text { x100) }\end{array}$} & \multirow{2}{*}{$\begin{array}{l}\text { Percent } \\
\text { age } \\
\text { cover } \\
2010\end{array}$} & $\begin{array}{l}2015 \\
\text { area }\end{array}$ & $\begin{array}{l}\text { Percent } \\
\text { age }\end{array}$ & $\begin{array}{l}\text { Percent } \\
\text { age }\end{array}$ \\
\hline & & & & & & & $\begin{array}{l}\text { (ha } \\
\text { x100) }\end{array}$ & $\begin{array}{l}\text { Cover } \\
2015\end{array}$ & $\begin{array}{l}\text { Cover } \\
2020\end{array}$ \\
\hline $\begin{array}{l}\text { Protected } \\
\text { area }\end{array}$ & 359.1 & 56.2 & 350.1 & 54.8 & 331.2 & 51.9 & 331 & -0.91 & -0.91 \\
\hline $\begin{array}{l}\text { Grazing } \\
\text { lands }\end{array}$ & 14.4 & 2.2 & 3.6 & 5 & 9 & 1.5 & 7.8 & -13.3 & -10.2 \\
\hline $\begin{array}{l}\text { unprotect } \\
\text { ed area }\end{array}$ & 36.9 & 5.8 & 57.6 & 9 & 10.8 & 1.7 & 8.2 & -24 & -16 \\
\hline $\begin{array}{l}\text { Small } \\
\text { scale } \\
\text { farming }\end{array}$ & 188.1 & 29.4 & 193.5 & 30.2 & 214.2 & 33.5 & 332.7 & 55.3 & 55.5 \\
\hline $\begin{array}{l}\text { Tea } \\
\text { plantatio } \\
\text { ns }\end{array}$ & 41.4 & 6.4 & 35.1 & 5.5 & 73.8 & 11.5 & 75.3 & 2 & 2 \\
\hline
\end{tabular}

The findings in Table 2, indicated that as a result of lack of alternatives for sustainability by the adjacent local community, many of them engaged in the illegal activities in the park. It was revealed by the focus group discussions that scarcity of water, construction materials and affordable meat, some of them illegally entered the park to harvest bamboo poles for construction and has been going on from 2007 to 2020. The key informants agreed that there was encroachment and poaching carried out by the local community. This was reflected in the progressively increasing number of high number of snares from 2007 to 2020. This was said to be as a result of scarcity of meat which was coupled with high prices of meat and so some of the local community resorted to poaching to earn income and sustain their wellbeing. In addition, the results also showed that the number of beehives increased from 2007 up to 2013 reduced in 2014 and remained constant. This was attributed to deforestation and lack of where to place the bee hives. The focus discussion group agreed that the local community engaged in income generating projects and the key was beekeeping where the locals had no alternatives but placed their beehives inside the park. The results in Table 2 also revealed that as a result of lack of alternative water sources around the park, some of the local community illegally entered the park to fetch water. The scarcity of water was reflected in the high number of the illegal water cases recorded inside the park. The key informant added that the challenge of water had led to encroachment from the surrounding host community as indicated in table 2 . However, the findings indicated that poaching had reduced and it was attributed to strict and tough penalties levied on the culprits arrested. The findings also indicated that firewood collection still existed but the trend is declining and this was as a result of new energy sources such as agricultural residues, bio-gas, solar energy as well as stringent laws implemented by the park authorities. 
African Journal of Environment and Natural Science Research

ISSN: 2689-9434

Volume 4, Issue 4, 2021 (pp. 88-98)

www.abjournals.org

\begin{tabular}{|l|l|l|l|l|l|l|l|l|l|l|l|l|l|}
\hline Items & $\begin{array}{l}200 \\
7\end{array}$ & $\begin{array}{l}200 \\
8\end{array}$ & $\begin{array}{l}200 \\
9\end{array}$ & $\begin{array}{l}201 \\
0\end{array}$ & $\begin{array}{l}201 \\
1\end{array}$ & $\begin{array}{l}201 \\
2\end{array}$ & $\begin{array}{l}201 \\
3\end{array}$ & $\begin{array}{l}201 \\
4\end{array}$ & $\begin{array}{l}201 \\
5\end{array}$ & $\begin{array}{l}201 \\
6\end{array}$ & 2017 & 2018 & 2019 \\
\hline snares & $\begin{array}{l}154 \\
2\end{array}$ & $\begin{array}{l}185 \\
5\end{array}$ & $\begin{array}{l}201 \\
0\end{array}$ & $\begin{array}{l}103 \\
0\end{array}$ & $\begin{array}{l}105 \\
0\end{array}$ & $\begin{array}{l}181 \\
0\end{array}$ & $\begin{array}{l}175 \\
8\end{array}$ & $\begin{array}{l}176 \\
2\end{array}$ & $\begin{array}{l}163 \\
0\end{array}$ & $\begin{array}{l}142 \\
1\end{array}$ & 1011 & 1281 & 1324 \\
\hline $\begin{array}{l}\text { Bamboo } \\
\text { \& wood } \\
\text { cutting }\end{array}$ & 68 & 43 & 9 & 32 & 45 & 38 & 47 & 31 & 24 & 33 & 38 & 35 & 22 \\
\hline $\begin{array}{l}\text { Fire } \\
\text { wood }\end{array}$ & 432 & 445 & 354 & 460 & 259 & 238 & 224 & 164 & 137 & 122 & 115 & 165 & 127 \\
\hline $\begin{array}{l}\text { Bee } \\
\text { hives }\end{array}$ & 67 & 116 & 258 & 202 & 201 & 209 & 314 & 287 & 258 & 241 & 233 & 255 & 225 \\
\hline $\begin{array}{l}\text { Water } \\
\text { collectio } \\
\text { n }\end{array}$ & 727 & 152 & 252 & 198 & 200 & 201 & 200 & 232 \\
7 & 6 & 3 & 5 & 3 & 7 & 4 & 211 & 2136 & 2328 & 2016 \\
\hline $\begin{array}{l}\text { Poachin } \\
\text { g }\end{array}$ & 0 & 0 & 1 & 2 & 2 & 3 & 3 & 1 & 2 & 1 & 2 & 0 & 2 \\
\hline
\end{tabular}

Findings from focus group discussions revealed that there were causes of illegal activities in the park by the local community. According to the respondents as indicated in Figure 1, the majority, $27 \%$ of the respondents, agreed that shortage of land in the area surrounding the park influenced them to seek alternatives by illegally harvesting the park resources to sustain their wellbeing. Also $23 \%$ agreed that it was as a result of poverty which prompted them to search for alternatives to sustain their livelihood. They argued that lack of income pushed them into illegal activities to increase their wellbeing. Additionally, another factor highlighted was illiteracy as mentioned by $20 \%$ and this was emphasized that lack of qualifications makes it difficult for them to get high paying jobs which was the reason why they supplement on the meagre incomes by encroaching on the park ecosystem. The respondents argued that due to high population pressure as highlighted by $16 \%$ of the respondents, was another key factor that had led to encroachment on ecosystems. They emphasized that as population increased, demand for more firewood, timber, land for agriculture and settlement. High affinity for these requirements forced the local community to engage in illegal activities and as a result degradation and reduction in size of the ecosystems. Finally, the results indicated that the respondents pointed out that another influencing factor was the lack of harmonization of the laws which was mentioned by $14 \%$ of the respondents. They argued that most times the laws conflict and lead to illegal activities because some laws provide for sustainable use of park ecosystems while other laws prohibit the harvesting. 


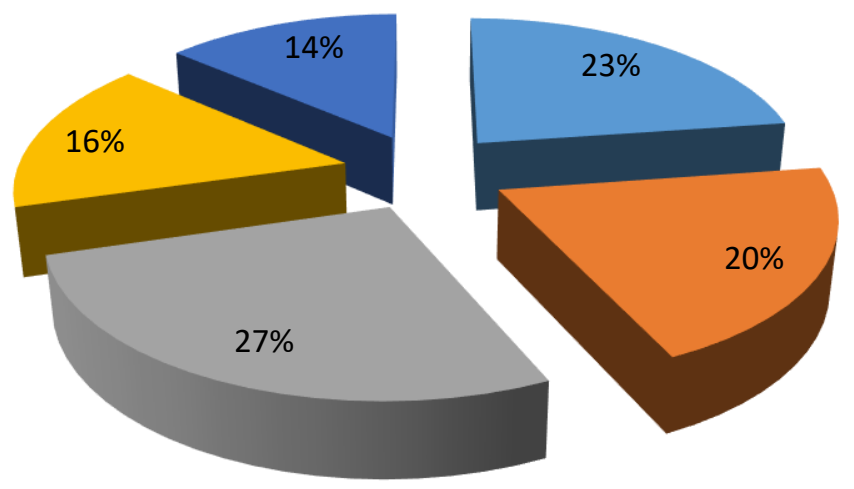

poverty

-illiteracy

- land shoratge

population pressure

harmonization of laws

\section{DISCUSSION}

The results indicate that ecosystems were encroached on by the local community adjacent to the park. It was discovered that the ecosystem size had changed majorly from 1973 and the size dwindled due to influencing factors such as poverty, high population density, shortage of land and illiteracy. The reason behind was that the local community were left without any option but to encroach on the ecosystems for their wellbeing. Over harvesting of ecosystems led to dwindled tangible goods as well as the reduced cover area of the ecosystem which impacted on local community wellbeing. These findings were in agreement with the authors such as (Geist and Lambin, 2002) who found out the poor are usually the ones who are highly dependent on the ecosystem of renewable goods and services. This was because these ecosystems generate several resources namely food, medicine, fuel wood, timber products, revenue from small businesses and construction materials (Bell and Morrison, 2015). Additionally, De Groot and Boumans, (2002), also highlighted that as a result of ecosystem disturbance, may arise due to the impacts from sectoral activities which directly depend on the natural capital such as fishing, agriculture, mining and grazing and so need to be assessed before grave mistakes are made. In the same line the consequences of such as timber harvest, water harvest, and fertile soil use need to be assessed in light of the extent of their disturbance on ecosystem renewable goods and services by the local community. (Falvio, 2008). The findings also revealed that the local community activities degraded the forest cover size which also led to reduction in the ecosystem goods for their wellbeing. The reduction in the quantity and quality of the tangible goods obtained from the park led to continuous harvest of the ecosystem goods which disturbed the ecosystems. These findings were in agreement with the earlier researchers who emphasized that for instance world fisheries stocks are dwindling, due to overfishing, while $40 \%$ of the suitable agricultural land has been degraded in the recent past by erosion, salinization, compaction, nutrient depletion, pollution, urbanization and settlements. Also, other anthropogenic induced problems include alteration of the nitrogen cycles, phosphorous, sulphur, and carbon cycle the challenge, There were brought about by the increasing demand for ecosystem renewable goods and services was complicated due to the increasingly serious perturbation in terms of inability of the ecosystems to offer these benefits which affects the local community wellbeing. These challenges in several parts of the world are greatly attributed to limited knowledge and understanding of the local community 
(Bogmann, et al 2000; Dasgupta, 2001). In the same argument other researchers such as (Williams, 2011; Greenfacts, 2005 and Geist, 2002) argued that ecosystem degradation tends to ham majorly the rural local community and had more direct and severe impact on economically poor people. The depletion of the renewable ecosystem goods has great implications on the livelihood of the local community. This is because wellbeing has key aspects that must be noted, namely the basic material for a good life, freedom and choice, health, good social relations and security. Therefore, lack of ecosystem benefits disrupts the wellbeing of the local community in rural areas and poor countries (Pearce, 2006).

\section{CONCLUSION}

It was concluded that ecosystems in and around Volcanoes National Park were disturbed and this affected the size of the cover area as well as the quantity and quality of the tangible goods derived. The reasons for disturbance were due to factors such as poverty, population pressure, shortage of land for agriculture and settlement. In conclusion the local community encroached on the ecosystems majorly to harvest timber, fuel wood and construction materials, further conclusively ecosystem degradation was also brought about by the scarcity for land for cultivation since the majority of the local community relied on subsistence farming and grazing of cattle. It was also concluded that the ecosystem disturbance was brought about by poaching the animals and it was indicated by the high numbers of wildlife snares. Finally, in conclusion, over exploitation of the ecosystem tangible goods had led to dwindling of the goods obtained. The dwindled harvested resources also negatively affected the local community wellbeing because of the reduced income and crop yields due to reduced ecosystem size and reaction in soil fertility.

\section{RECOMMENDATIONS}

$>$ Under this section the study recommended that the park management should set up mechanisms of empowering the adjacent local community so that they get sustainable incomes to improve their wellbeing and not get engaged in illegal activities in the park

$>$ It was also recommended that the local community should set up income generating ventures such as beekeeping, and handcraft activities to widen their income generating activities on top of subsistence agriculture that will better their wellbeing.

$>$ Finally, it was recommended that the government should come up with viable projects that are inclusive and involve the local community to engage in economic activities that will improve their wellbeing

$>$ Finally, the government should formulate policies that motivate the local community to support their effective implementation to avoid situations where the local community feel sidelined and yet they need to improve their wellbeing 


\section{REFERENCES}

Allen, C. R.,G. S. Cumming, A. Garmestani, P. D. Taylor, and B. H. Walker. (2011). Managing for resilience.Wildlife Biology 17:337-349. Annual Review of Ecology Evolution and Systematics 35:557-581.

Barrett, C. B., E. B. Barbier, and T. Reardon, (2001). Agro-industrialization, globalization, and international development : The environmental implications. Environment and Development Economics, 6,419-433.

Bell, J., and T. Morrison. (2015). A comparative analysis of the transformation of governance systems: Land-use planning for flood risk. Journal of Environmental Policy and Planning 17:516-534

Brown, B. (2009). Is humanity doomed by its own avarice \& greed? Retrieved December (2021) from :http://www.forestcouncil.or/tims-picks/view.php?id=1581

Bugmann, H., M. Lindner, P. Lasch, M. Flechsig, B. Ebert, and W. Cramer, (2000). Scaling issues in forest succession modeling. Climatic Change ,44,265-289.

Butler, C. D., (2000). Inequality, global change and the sustainability of civilization. Global Change and Human Health,1(2),156-172. Capability and sustainability centre, Cambridge, UK.

Cinner, J .E., and T. R. McClanahan. (2015). A sea change on the African coast? Preliminary social and ecological outcomes of a governance transformation in Kenya fisheries. Global environmental change 30: 133-139

Contreras -Hermosilla,A., (2000). The Underlying Causes of Forest Decline .CIFOR Occasional Paper 30,Center for International Forestry Research, Bogor, Indonesia.

Cumming, G. S., T. H. Morrison , and T. P .Hughes. (2017). New directions for understanding the spatial resilience of social-ecological systems. Ecosystems 20(4):649-664.

Daily ,G.C.(ed), (1997a). Nature's Services: Societal Dependence on Natural Systems. Island Press, Washington,DC,392pp.

Daily, G. C.,( 1997b). Introduction:What are ecosystem services? In:Nature's Services:Societal Dependence on Natural Ecosystems,G.C. Daily (ed),Island Press, Washington,DC, 1-10.

Dasgupta ,P.,(2001). Human Well-Being and the Natural Environment.Oxford University Press,Oxford,305 pp.

De Groot,R.S.,M.Wilson, and R.Boumans,(2002). A typology for the description,classification, and valuation of ecosystem functions, goods and services.Ecological Economics,41(3),393-408.

Eftec (2006), Valuing our Natural Environment. Report for Defra:http://www.defra.gov.uk/wildlife-countryside/natres/pdf/nr0103-full.pdf

Falvio Comim. (2008). Poverty and Environmental Indicators, Capability and sustainability indicators, Cambridge., U.K

FAO, (2003). FAOSTAT Statistics Database. (online) Food and Agriculture organization of the United Nation ,Rome. Available at http://www.fao.org/FAOSTAT.

Farber, S. C., R. Constanza , and M. A. Wilson ,(2002). Economic and ecological concepts for valuing ecosystem services. Ecological Economics,41,375-392,

Folke, C. ,S. Carpenter, B. Walker,M .Scheffer, T. Elmqvist, L. Gunderson, and C.S. Holloing (2004). Regime shifts and resilience, and biodiversity in ecosystem management. Annual review of ecology, Evolution and Systematics 35; 557-581. 
Geist, H. J. and E. F. Lambin, (2002). Proximate causes and underlying driving forces of tropical deforestation.BioScience, 52(2),143-150.

Greendacts.T. (2005). Ecosystem Change:3. How have Ecosystem changes Affected human well-Being and poverty Alleviation?, Retrieved December 2009 from :http://www.greenfacts.org/ en/ecosystems/millennium-assessment -2/3-human -well being poverty.htm

Groom, N/J., Meffe, G.K., and Carroll C.R. (2006). Principles of Conservation biology. Sinnuaer Associates Sunderland. Massachusetts, USA.

Holling. C.,S, (2004). Regime shifts,resilience, and biodiversity in ecosystem management.

Into National Development Planning, UNEP, Nairobi,Kenya

Lester R.Brown. (2009).Shrinking Forests: The Many Costs,Lester

Macneil ,M.A.(2013). The politics, science and policy of reference points for resource management .Environmental Conservation 40:297-301. Making, PowerPoint presentation, Retrieved December 2009 from :http://www.wri.org/publication /

Mastrandrea, M. D., and S. H. Schneider (2004). Probabilistic integrated assessment of "dangerous"climate change. Science 304:571-575.

Millennium Ecosystem Assessment (2005). Island Press, Washington, DC.

Myers, R. A., and B. Worn.(2003). Rapid worldwide depletion of predatory fish communities .Nature 423:280-283.

Pearce D, Atkinson G and Mourato S (2006),Cost -Benefit Analysis and the Environmental :Recent Developments. OECD. Preliminary social and ecological outcomes of a governance transformation in Kentan fisheries. Global Environmental Change 30:133139.

Rosegrant, M. W. X. M. Cai and S. A. Cline .(2003).Will the world run dry? Global water and food security .Environment 45:24-36.

Sachs ,J. D., and W.V. Reid. (2006). Environment-Investments toward sustainable development .Science 312:1002-1002.

Sachs, J. D., and W. V. Reid .2006.Environment -Investments toward sustainable development. Science 312:1002-1002.

Schneider, S. H. (2001). What is 'dangerous' climate change? Nature 411:17-19.

Sinauer Associates, Sunderland ,Massachusetts, USA.

Turner, M. G., R. H. Gardner, and R.V.O' Neill. (2001).Landscape ecology in theory and practice :pattern and process .Springer-Verlag, New York.

United Nations Development Programme-United Nations Environment Programme PovertyEnvironment Initiative (2008). Making the Economic Case : A Primer on the Economic Arguments for Mainstreaming Poverty -Environment Linkages

Williams, B. K. (2011). Adaptive management of natural resources -framework and issues. Journal of Environmental Management 92:1346-1353.

World Resources institute. (2008). Nature for People's Sake Integrating Ecosystem Services in Public Decision 